\title{
Teacher and Students' Talk in Speaking Classroom Interaction
}

\author{
Mellany \\ Institute Agama Islam Negeri (IAIN) Bengkulu \\ mellany@gmail.com \\ Risnawati \\ Institute Agama Islam Negeri (IAIN) Bengkulu \\ risnawati@iainbengkulu.ac.id \\ Fera Zasrianita \\ Institute Agama Islam Negeri (IAIN) Bengkulu \\ fera@iainbengkulu.ac.id
}

\begin{abstract}
Classroom interactions are typical class situations where verbal contact is dominant, which means that the teacher has a significant impact on the students speaking ability. Classroom interaction and speaking ability have related to createdinteraction on teaching classroom process. This study purpose at analyzing the realization of classroom interaction especially teacher talk and students talk occurred during teaching speaking class. The data were taken from SMA Negeri 3 Seluma in the form of observation, interview, and documentation. The data then were analyzed by the framework adapted from Flanders Interaction Analysis Categories (FIAC). The findings showed that the classroom interaction most dominant is the teacher while students during speaking class. It also described those teacher roles during classroom interaction as director, manager, and facilitator. The study recommends the teacher support students to actively speak when learning the classroom process. Finally, this study suggests a further study to find various frameworks in analyzing classroom interaction discourse which covers different abilities.
\end{abstract}

Keywords: Classroom Interaction, Speaking Ability, FIAC, Student Talk, Teacher Talk

\section{A. Introduction}

The aim of learning English is to communicate well and to explain it in all activities. Inside the classroom, there is a class language that is normally of a natural learning and communication nature. According to Paul, class language is a good way for students to learna language and to connect English with what they feel (Paul, 2015). Class language is created because there is a classroom interaction. Classroom interactions are normal classroom situations where verbal communication is dominant, which means that the teacher has an important influence on the student and that the student has a great influence on the teacher as well (Flanders, 1976)

Teachers and students are two objects that become important point's in-class interactions. Interactions in the classroom are created when teachers try to communicate with students as a teaching-learning process in the classroom. As students engage in the classroom, 
their ability to talk is important for students. Speaking ability can enable students to connect and communicate well. Language teaching mainly teaches the ability to speak is very important as learning can benefit learners through verbal engagement and contextual learning (Kasim, 2013) Teaching the ability to communicate will help students improve experiences in contact with students. Classroom communication is one of the vital structures of the learning process in school. Classroom interaction is action-reaction or a reciprocal influence between an individual (Veronica, 2015). While interaction classroom is fundamental of classroom pedagogy, because all happens in a classroom it is a process of activities person to person interaction (Ellis, 1999). Interaction is mutual communication between two or more people who have created interactions, interactions that can be spoken, body language or non-verbal communication. Interaction can be defined as face-to-face and can be verbal, written, or nonverbal (Robinson, 2018). Thus, the interaction is when someone meets a person, a community, and needs a dialog to connect from one person to another. The classroom is a component of the teaching and learning cycle. Classroom interaction in teaching processes has a significant roleto play in the learning process. The method from teaching that has been said to be effective and when engaging in the learning process will encourage students to learn lessons such as learning English in the classroom. The teacher naturally communicates by speaking English that is acceptable to the level they learn in the classroom. Classroom interactions are typical class situations where verbal contact is dominant, which means that the teacher has a significant impact on the student's speaking ability and the student has a great influence on the teacher as well (Flanders, 1976).

Students are part of the teaching and learning process, where they are objects that are required to gain knowledge. Certainly within the scope of the classroom students are expected to be able to contribute and interact with students and teachers who teach in class, of course, skills needed in speaking in that regard. Students must have the ability to speak, this is important because, without the interaction of students in the classroom, the class will feel passive when students do not respond to the lessons delivered by the teacher teaching in the class. Asian children have the opportunity to read, write Besides, and listen to English both in class or at home but some of them do not get the opportunity to speak English at home even outside (Paul, 2015).

The teacher is a means as well as a guide in the world of education, in addition to conveying the knowledge needed by students; of course, teachers must speak in front of their students. Teachers are indeed guided to be able to speak in public and must have the ability to 
speak. Teachers need to use language that supports the community climate that we want in the classroom, so we teach that language too, we want children to talk to each other respectfully, so we teach this too (Deborah \& Charlotte, 2006). Therefore the teacher's speaking ability is needed in the world of education especially in the classroom when teaching and learning.

To measure, classroom interaction, FIAC is used by researchers. FIAC is a methodology developed by Dr. Ned Flanders (1970, cited in Smith 1976) to examine a variety of types of experiences in the classroom during the teaching and learning process (Smith, et al, 1976). There are ten sections in the study to understand and explain the dialogue that takes place in the classroom between the teacher and the students during the learning process. The aim of using Flanders the Interaction Analysis category is to provide innovative ideas for shifting the position of the teacher in the classroom and for the masteryof students who are more actively involved in the classroom. That's why researchers have chosen FIAC to see interactions in the classroom to improve students' speaking skills. Calculations are calculated based on predetermined categories, provisions for the understanding of teachers and students have not yet been developed (Smith, et all, 1976). FIC (Flanders Interaction Category) is believed to have the potential to improve the quality of conversations in which students and teachers speak briefly and correctly in the classroom.

\section{B. Research Methodology}

This research used mix method of teacher and students' interaction classroom is analysis in this research. Mix methods are consisting of qualitative and quantitative approaches. The qualitative approach of researchers should use oneself as an instrument because non-human instruments are difficult to use flexibly to capture the variations that occur, the researcher must be able to reveal social phenomena in the field by mobilizing all functions of the senses (Lincoln and Guba, 1985). Qualitative approach research usually uses an explanatory design, in which the object of study is explanatory research is to test the relationship between variables which is hypothesized (Mulyadi, 2012).

In this type of research, there is a hypothesis that will be tested for correctness. The collecting data are observation sheet (students and teacher classroom interaction), interview, and documentation. There have five classes of Study at Eleven Grade Students of SMA Negeri 3 Seluma. The researchers will choose one class to observe; it is Eleven MIPA 3 classes that consist is seventeen students by their participation in English learning in the classroom. This 
research will be using Flanders Interaction Analysis Categories (FIAC). WithFIAC will knowhow classroom interaction develop speaking ability is and in the analysis there are ten categories to learn and clarify the conversation that occurs in the classroom between the teacher and students during of learning process.

\section{Finding and Discussion}

In the following, the writer provides the result of observations obtained to know how classroom interaction develops speaking ability. Here was the result the writer explained of observation classroom interaction below. The first step is analysis classroom interaction and transcribing from videotaping after teaching English in class, after that observer to classifying ten categories of the Flanders interaction analysis category (FIAC). Here was the result the writer explained of observation classroom interaction below.

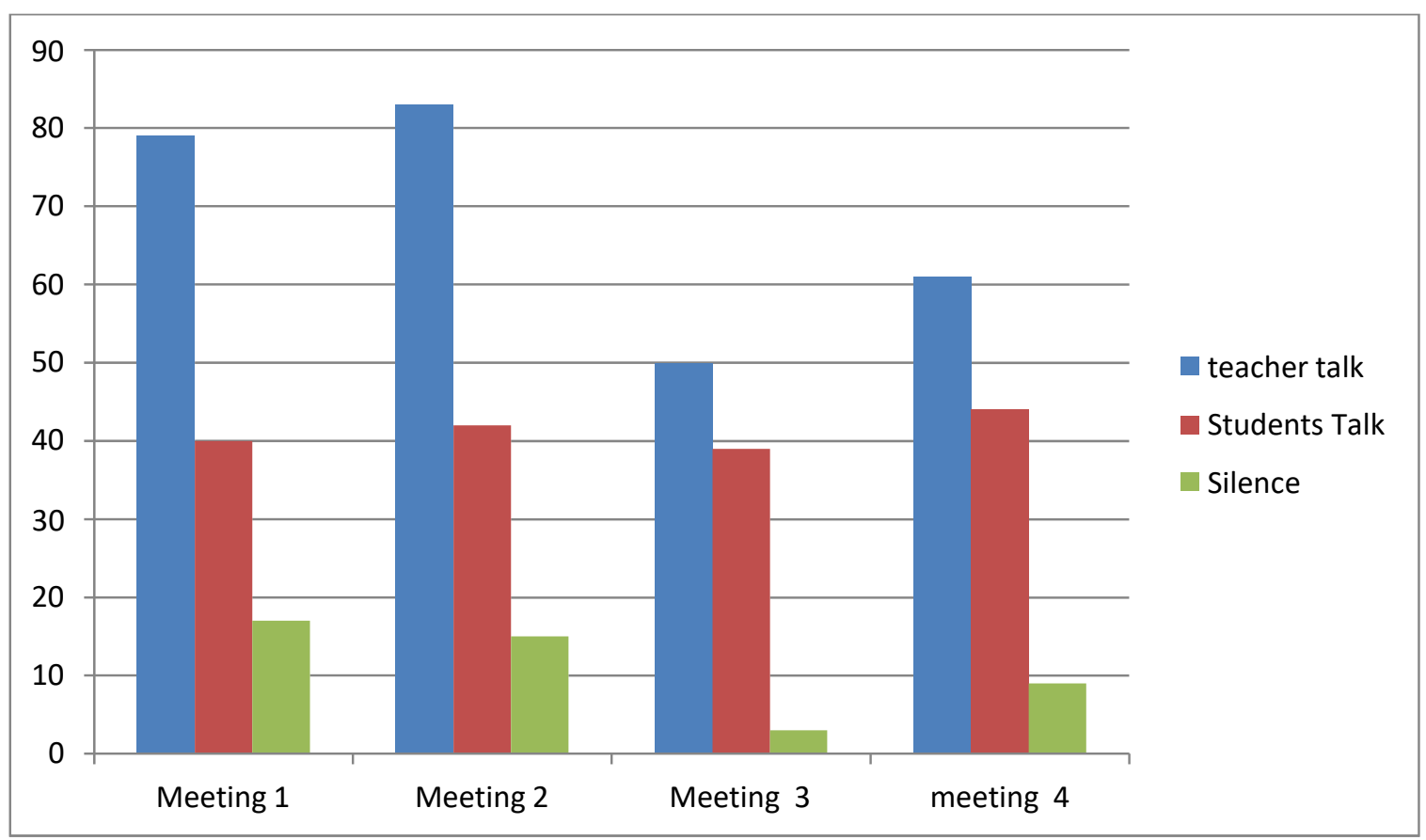

\section{Graph 1. Classroom Interaction at Eleven Class SMA Negeri 3 Seluma}

Based on the result of the table observation from classroom interaction on student class of eleven, then in the table explained that part of teacher talk more is dominated than pupil talk and silence. Part of teacher talk (TT) explaining that teachers dominant than students in classroom interaction. It happens because students did not respond to interaction by the teacher in the classroom and that gives effect to students not active in the classroom. The below are classroom interaction situation such as:

\section{Teacher Talk}

Teacher talks here refer to talks or expressions the teacher used in classroom interactions. The talks include (1) accepts feelings, (2) praise or encouragement, (3) accepts or uses ideas of students, (4) asking question, (5) lecturing, (6) giving directions, (7) criticizing or justifying authority. 


\section{Accepts feelings}

Accepts and clarifies about attitude or feeling tone of students. Feeling positive or negative about students and then predicting is included of accepts feeling. These were the examples from the result of observation:

Teacher : Okey students, how are you today? 
Student $\quad$ :Fine mam, and you?

Teacher : Fine too....

\section{(source: Observation 1, teacher and student)}

From the dialog above we can see the teacher know the condition with student's feeling. And students feeling is positive, in interaction created by teacherand students.

\section{Praise or encourages}

It is more be to action and behavior, give support for students and give awarded for students when students understand with they are learning in the classroom. These were the examples from the result of observation when students doing an assignment from the teacher front of the class with their friends:

Teacher : Give an example of a suggestion?

Students : I suggest that you study hard...

Students : of course...

Teacher : okay good, give applause.....

(source: Observation 1, teacher and student)

From a conversation above, the observer sees that teacher gives praise to students when they can to give an example of suggesting to their friends.

\section{Accepts ideas}

Accepts idea is developing students' suggested, opinion to talk with student friend and teacher at the classroom. Then, also give push students to speak more in the classroom to created interaction. These were the examples from the result of observation:

Students : Mam, I will give example about suggest, "Randi Isuggest that you buy shoes black"

Teacher : Iqbal, black shoes not shoes black...because adjectiveand then noun not a noun to adjective...do you understand students?

Students : yes mam....

(source: Observation 1, teacher and student)

From the dialogue above, the student gives the idea to the teacher, and then theteacher to try to explain more detail about the material to students understand and not confusion meaning. 


\section{Asks questions}

Asks question is asks content or procedure which related with the material, it is based on teacher and students to answer the question it. These were the examples from the result of observation:

Teachers

suggestion?

(source: Observation 1, teacher and student)

From the sentence above, the teacher to try asks a question to students to created interaction and develop knowledge student about material learning English.

\section{Lecturing}

Lecturing is giving facts or information about material learning in the classroom during when teaching process. These were the examples from the result of observation:

Teacher : I will write some expression about suggestion "Let's, How about, What about, I say, I don't think, I suggest, and the others"...

(source: Observation 1, teacher and student)

From a statement above, the teacher explained or delivered information about the material to students.

\section{Giving direction}

Giving direction is an order to students expected to comply. These were the examples from the result of observation:

Teacher : Students, I want you to give suggestions to your friends...

(source: Observation 1, teacher and student)

From the sentence above, the teacher gives direction to students. It is to creating interaction with teachers and students.

\section{Criticizes or justifies authority}

Criticizes is to statement intended to change students' behavior from non- acceptable to acceptable pattern. These were the examples from the result of observation:

Teacher: So, I hope you use the English language in yourclassroom, oke?

Students

Teacher

(source: Observation 1, teacher and student)
: yes mam...

: when you do not use English, just silent.... 
From dialogue on above, teacher as a facilitator to manage the class system to lead teacher rule when a student in the class.

\section{Students Talk}

Pupil talk (students talk) here refers to talks or expressions the students used inclassroom interactions. The talks include (8) Pupil-talk-response and (9) Pupil-talk-initiation.

\section{Student-talk-response}

Pupil-talk-response is talking by students in response teacher at classroom andteacher initiates' contact or solicits students' statement in the situation. These were theexamples from the result of observation:

Teacher : Do you understand?

Students : Yes mam....

(source: Observation 1, teacher and student)

The dialogue above explained the interaction between teacher and students in the classroom.

\section{Students-talk-initiation}

Pupil-talk-initiation is a talk by students that they initiate, express a new idea, own idea, and develop an opinion. These were the examples from the result ofobservation:

Student : Another example of giving suggestions is "Risma I suggest that you wear a pink jacket".

(source: Observation 1, teacher and student)

From the dialogue above, students tell about students' opinions about thematerial and develop students' sentences.

\section{Silence}

Silence or confusion is the conditions of pause, a short period of silence, or confusion in communication that cannot be understood by the observer. These were the examples from the result of observation:

Teacher : what the meaning of suggesting..???Students (silence)

(source: Observation 1, teacher and student)

From the dialogue above, the teacher giving interaction to students about the question but the students not respond or just silent, it is happening because students do not know about the answer to the question by teacher. 
In an observation on four meetings, have result from classroom interaction between teachers and student during learning process on English subject. Certainly, on four meeting observations, the writer found that part of teacher talk (TT) more dominant from 273 frequencies while pupil talks (PT) students in a class. Teachers give much interaction in the classroom during students, but the purpose of the teacher is to give simulation for studentscan more active in the classroom. The teacher is dominant during the teaching process. Because teachers give interaction the first, such as control condition class, explained grammatical rule, and controlled students talk. The pattern of classroom interaction is from teacher talk (TT), the concluded that teacher as a manager, director, facilitator, and controller (Ami, 2013). Because teachers have important rules in teach students during the learning process.

Besides, on result classroom interaction during the learning process, part of pupil talk (PT) or students' is little interaction in the classroom. Only 165 frequencies during the learning process in class, while teacher talk which has much frequency during interaction in the classroom. Actually, students want to spoke more in class, but students have difficulty in the show what students feel. Observer concludes some problem why students few interactions in class during learning English subject. The first is students' lack of knowledge about vocabulary in English. The second is students confused with grammatical and not confidents with what students say, it makes students passive in class. The last, that English a foreign language for students, not a second language such as Indonesians. English is not used as everyday communication in Indonesians. It makes it students difficult to used English for communication each interaction in the classroom. Because of that, make students not active in classroom interaction.

Interaction classroom compares with pupil talk, part of silence is little when learning process. Frequencies 44, is good because compared with a silence that pupil talk is getting much frequency. Silence has happened in the classroom because students do not respond to an interaction from the teacher. Such as the problem explained above, from vocabulary, grammatical, and second language. Relation with the result of interview and observation, that teacher has a big influence in interaction classroom while students. As a facilitator, the teacher has to rule control the classroom to make students to response teacher interaction. When students were a response to the teacher, it created interaction in the classroom. One of the problems students that English is a foreign language and students not confident speak use English. Classroom interaction can be provided by teachers can be lucrative for improving speaking skills (Mackey, 2016). Therefore teachers should help and make a strategy for students to develop speaking ability. 
The observer gives suggest that teacher dominant while students. The first is teacher gives opportunities for students to talk more during class. The second is, teachers created different strategies for teaching to make students confident and active to speak up. The last is teachers must know what students need in learner English subject to the purpose the problem that feels with students when teaching and learning process.

\section{Conclusion}

There are a few focuses to be conducted in this consider. Firsts, in line with the realization of verbal classroom interaction, there are a few categories that are for the most part used by the educator and understudies amid the talking movement. Moment, in terms of the categories that are generally utilized by the educator, it can be concluded that the teacher'sroles are as a supervisor, chief, facilitator, and controller. The interaction between students and teachers generally employments English dialect since the school adjusted universal educational modules. In any case, based on the interaction, there are a few issues that are experienced by the teacher. In spite of the fact that interaction generally utilized English for communication, the interaction is still overwhelmed by the educator which was appeared from the perception and meets. Educator too finds troublesome to understudies how to talk more and discover the methodologies.

In arrange for encourage ponder almost teacher conversation and students talk, there are a few suggestions that can be utilized, to be specific: first, the teacher conversation and teacher can be more meaningful curiously and successful when educator gives more openings to the students to the conversation and the second distinctive educating procedures in making understudy certain and prepared to the conversation are prescribed talking is an imperative ability which happens in spontaneous circumstances. The third, for future, consider, it is recommended to capture instructor conversation and students' conversation not as it were in talking ability but too totally different aptitudes such as composing, listening and perusing. It is since when the educator instructs composing, the teacher conversation moreover will be distinctive when the teacher perusing and tuning in. and the last, additionally for assist study that centered on classroom talk investigation, it is prescribed discover more various system in analyzing classroom talk.

Therefore, future studies are recommended to English teachers and students to can impact their interaction during verbal classroom interaction and give more to practice their language. The teacher to find more various frameworks in analyzing classroom discourse to 
help give more information about classroom interaction, especially for further study.

\section{References}

Ami, F.M. (2013). A Study of Teacher Talk and Student Talk in Verbal Classroom Interaction to Develop Speaking Skill for Young Learners. Journal of English and Education. Study Program of Indonesia University of Education. 1(1), 1-10.pdf

Amatari, V.O. (2015). The Instructional Process: A Review of Flanders' Interaction Analysis in a Classroom Setting. Wilberforce Island, Amassoma, Bayelsa State, Nigeria: Science Publishing Group. International Journal of Secondary Education 3(5): 43-49.pdf

Diffily, D \& Sassman, C. (2006). Positive Teacher Talk for better Classroom Management. Scholastic Inc:New York. Page 9.

Ellis, R.(1999). The Study of Second Language Acquisition. Oxford University Press.

Hanna, S. (2017). Classroom Interaction in Teaching English as Foreign Language at Lower Secondary Schools in Indonesia. Australian International Academic Centre PTY.LTD.

Bafadal, I. F. (2019). The an Analyses of Students Speaking Ability on Specific Purpose of Learning. Linguistic and English Language Teaching Journal.pdf

Saeed, K.M. (2016). The Role of Learner-Learner Interaction in the Development of Speaking Skills. Theory and Practice in Language Studies, Vol. 6, No. 2, pp. 235 241.pdf

Kingen, S. (2000). Teaching LanguageTest Development (speaking Test). Center for applied Linguistics. New Jersey: Lawrence Erlbaum Associates, Publisher.

Smith \& Cale, E. (1976). A Latitudinal Study of Pre-Service Instruction in Flanders' Interaction Analysis Categories. Arizona State University. Office of Education (DHEW): Washington, D.C.

Yvonna, S. L \& Egon G. G (1985). Naturalistic Inquiry. Beverly Hills: Sage Publications, 52. 